\title{
ETHNIC PROCESSES IN KHIVA AND ITS NEIGHBORING COUNTRIES IN "SHAJARAII TURKISH" BY ABULGAZI BAHODIRKHAN
}

\author{
N.Sh. Hamraeva \\ Independent Researcher Karsu,, Uzbekistan
}

\section{ABSTRACT}

The article provides a brief overview of the socio-political, economic and cultural life of Khiva and neighboring regions in the Middle Ages, coverage of ethnic processes in the work of Abulgazi Bakhodirkhan "Shajaray Turkish".

KEYWORDS: - Political situation, ethnic composition, ethnogenesis, "Tupa", tribe, clan, people, nation, kungirat, socio-political, economic, cultural.

\section{INTRODUCTION}

The peoples of Central Asia have been in ethnic, economic and cultural relationship constantly and have become interfered with each other for many centuries. The interaction of the Iranian speaking population with the semi-nomadic population of the steppes surrounding the region is considered the main driver of the ethnic history and the ethnic processes of the Khorezm population that have developed in its territory since ancient period.

The great medieval encyclopedic scholar Abu Rayhan Muhammad ibn Ahmad Beruni (9731048) also noted that the language of the Khorezmians was close to the language of the Iranians and the people of Sogdia. Academician
K.Shoniyazov, who analysed deeply the ethnogenesis of the Uzbek people, said that "as for the Khorezmians, although they are a branch of the Iranian "Family Tree" and a stream of the Iranian river, they follow the Sogdians in determining the beginning of the year and where to put extra days [1]." He concluded his idea like this: "Even though the Khorezmians are close to the Iranians, it is wrong to think of them as the pure Iranians. the Khorezmians had their own language, script, name and consciousness in the early Middle Ages [2].

\section{T HE MAIN FINDINGS AND RESULTS}

During the XIV-XVIII centuries, the political situation in Khorezm was complicated, and the conflicts that took place affected the ethnic composition, location and number of the 
CURRENT RESEARCH JOURNAL OF HISTORY 2(12): 17-19, December

2021

DOI: https://doi.org/10.37547/history-crjh-02-12-04

ISSN 2767-472X

(C2021 Master Journals

Crossref doi

81 Google

Accepted 15 th December, 2021 \& Published 20 th December, 2021

country's population. During the XIV-XVI centuries a certain part of the population of Khorezm was moved to Movarounnahr. In particular, during his last expedition to Khorezm (1388) Amir Temur captured the city of Urgench and moved the majority of the city's population (mainly artisans) to Samarkand. Most of them are located in the middle and lower parts of Zarafshan valley. Shoniyozov explains that in the late 19th and early 20th centuries, groups known as "urganji" met in these areas [2]. According to Abulgazi Bahodirkhan (1603-1663), khan of Khiva Ubaydullah (1533-1539), one of the Shaybanids, "conquered Urgench and brought its people to Movarounnahr [3]."

It should be noted that in the study of the socioeconomic life of Khorezm in the XVI-XVII centuries, the work by Khorezm historians Munis and Ogahi "Firdavs ul-Ikbal" on the migration of the population is also important. Essential information about the Urgench and Khiva peoples who were moved to Bukhara by Ubaydullah in 945/1538 and Abdullakhan II Shaibani in 1002 / 1593-1594 was given in that work as well [4].

It is described that during the reign of Khiva khan Isfandiyarkhan (1623-1645) a large part of the population fled to Bukhara, Samarkand, Mangit ulus and Kazakhs from the oppression of the Turkmens who supported his coming to power and the Karakalpaks living in Khorezm moved to Yangisuv and Syrdarya rivers under the pressure of Shergozikhan in 1726/1727. It is also worth noting the information about the state reforms of Abulgazi Bahodirkhan in order to stabilize the political, social and economic situation among the population [5]. In order to put an end to inter-tribal struggles, he divided the Uzbeks of the downstream of the Amudarya into four groups - "Tupa". In other words, uniting the Uzbek per two tribes into one community, he formed four pairs of groups: the Uyghur-
Nayman, the Bell-Qiyat, the Nukus-Mangit, and the Kangli-Kipchak. Along with Uzbek tribes, the work "Firdavs ul-Ikbal" also provides ethnographic materials about Turkmen tribes Ersari, Salur, Khurasansaluri, Soruk, Taka, Yovmut, Hasan Eli, Ali Eli, Hizr Eli, Goklan, Tevachi [5].

According to Abulgazi Bahodirkhan in "Shajarai Turk", the original word (Mongol) is "Mungul". Gradually, it began to be said as "Mongols" cause of common people couldn't pronounce it as Mungul. All Turks know the meaning of the word "Mung", it means "sorrow, sad". Its meaning is "simplehearted sorrow"; "Kipchak - Tan (Don) and Itil (Volga) and Yayik (Ural), which sit between these waters"; "They were sitting together with a troubled Turkmen," he said. Issyk-Kul and Chu and Talosh after landing in the Turkmen province; they settled for many years on the banks of these waters, he married a girl named Turkan who was the daughter of one of the sons of Tekashkhan (reigned 1172-1200) from the kings of Urgench. Sultan Muhammad Khorezmshah (reigned 1200-1220) was born from that marriage. The next example: "After the death of Toktogukhan (khan of the Golden Horde, who ruled from 1290 to 1312), Uzbekkhan (1312-1342) became khan at the age of thirteen. The whole tribes and territory were conquered according to the ways and rules of his ancestors. He gave gifts with respect to everyone's career. He made the whole people join religion Islam... . And then Juji was replaced by Uzbek [6]".

From the information about the tribes and clans of the Uzbek, the names of the groups and tribes mentioned in the play are very important. These are: Orlot / arlat, ogor, olakanotli, okli, aymok, bashkird, bayot, tot, totar, temirli, turumchi, turkish, turkman, taka, turbotli, tevachi, jobi, jomachi, chobichok, choboni, chigatoy, choni, khizir eli , khurasanli, kalaj, dukar, soik, solur, 
DOI: https://doi.org/10.37547/history-crjh-02-12-04

ISSN 2767-472X

(C2021 Master Journals

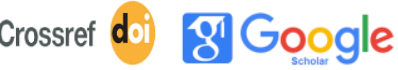

Accepted 15th December, 2021 \& Published 20 th December, 2021

surkhi / surki, sokar, saljuk, sultanli, savroki, sovchili, kurgoli, kurkin, larlik, kipchak, karatashli, kalmok, kyrgyz, chirayli, kutlar, lola, mangolian, mangit, nayman, mondi, yazir, yagmo, yovmut, yurti and others [7].

One of the most common clans among Uzbeks and Turkic people in common is Kungirot. In addition to Uzbeks, this clan occupies a significant place among Karakalpak and Kazakh clanes. However, their number was higher among other Uzbek clanes. In the 1920s, when the population was registered in the Gissar, Denau, Boysun, Sherabad, Qabodiyon, Qurghonteppa, and Kulob principalities in the southern regions of present-day Uzbekistan and Tajikistan, the clan Kungirat was the most. In this principality, 22.4 per cent of the total population consisted of clan Kungirat [8].

\section{Conclusion}

In conclusion, the work "Shajaraii Turk" gives a lot of information not only about Khorezm, but also about the socio-political, economic and cultural life of the neighboring regions, ethnic processes. For these reasons, it should be included in the list of valuable written sources on the history of Khorezm and neighboring regions.

\section{RefERENCES}

1. Abu Rayhan Beruni. Osar-ul-bokiya min alkuruni-l-holiya. $\urcorner$ - T., 1968 - p.83

2. Shoniyozov K. The process of formation of the Uzbek people. - Tashkent: Shark, 1968 - p 216.

3. Abulgazi Bahodirkhan "Shajarayi turk" .Tashkent, "Chulpan". 1992, - p.134.

4. Munis and Ogahi. Firdavs ul-Ikbal. Tashkent «Yangi asr avlodi» 2010, - p.87.

5. Allaeva $\mathrm{N}$. The composition of the population of the Khiva khanate (state) in the Middle Ages and the influence of ethnographic processes on it. - B. 15-18.

6. Abulgazi Bahodirkhan "Shajarayi turk" .Tashkent "Chulpan” 1992 - P.107

7. Doniyorov X., Family Trees and dialects of the Uzbek people. - T., 1968, p.35.

8. Bekmatov A. Kungirats. Newspaper "Kalb Kuzi". January, 1996. 